産業技術総合研究所 嵐

\section{1. 緒 言}

コジェネレーションシステムは省エネルギー，地球 温暖化防止に有効であり, 近年その普及が進んでいる。 しかし, 従来のコジェネレーションは発電容量が 2,000〜4,000kW 級のものがほとんどで, 中小規模の 住宅，店舗，あるいは事務所には導入し難い。これに 対してマイクロガスタービンコジェネレーションシス テム（MGT-CGS）は，容量が $30 \sim 100 \mathrm{~kW}$ 程度と小 型で発電効率も $25 \sim 30 \%$ と高いことから，上記のよ うな中小規模の建物への導入が今後増加することが予 想される。

MGT-CGS の導入に当たっては，他の熱電供給シス テムとの比較をおこなって省エネルギー性，環境負荷 に対する優劣を比較しなければならない。特に， MGT-CGS と他の熱電供給システムのいずれを選定す るか, あるいは既設システムへの代替に打いては, シ ステムのライフサイクルでの環境影響評価が不可欠で ある。これまでにも MGT-CGS を導入した時の運用 時のエネルギー消費量とそれに伴う $\mathrm{CO}_{2}$ の排出，コ スト等の評価に関しては研究例がある ${ }^{12)}$ 。それに対 して, 本研究では, 運用時だけでなく MGT-CGS の製 造時の $\mathrm{CO}_{2}$ 発生量まで着目したライフサイクル環境 性を論じ, システム選定の意思決定の一助とすること を目的とした。

さらに，建物にMGT-CGS を導入した場合の一例 として, 集合住宅, スーパーマーケットを選定し, こ れらの建屋に MGT-CGS を導入する際の省エネルギ 一性ならびに $\mathrm{CO}_{2}$ 排出特性について, 系統電力と吸 収式冷温水機よりなる従来型熱電供給システムと比較 した。

ライフサイクルアセスメント研究センター

つくば市小野川 $16-1$
紀夫，玄地 裕，八木田浩史，稲葉 敦

\section{2. システム}

本研究で対象としたマイクロガスタービンコジェネ レーションシステム（MGT-CGS）を，従来型熱電供 給システムと比較して Fig. 1 に示す。従来型システム は, 電力を系統電力から供給し冷温熱をガス焚き吸収 冷温水機により供給するシステムとする。MGT-CGS は, 電力をマイクロガスタービン発電機及び一部系統 電力から供給し, 温熱を発電排熱を熱源とする温水ボ イラにより，冷熱を温水吸収冷凍機により供給するシ ステムとする。所要熱量に対して廃熱量が不足する場 合は温水ボイラに補助燃料を供給して必要熱を確保す る。系統電力及びマイクロガスタービン発電電力の発 電効率, 及び冷温熱供給各機器の熱効率 (吸収式冷温 水機では COP) は Table 1 に示すとおりに設定した。 これらの数值は Fig. 1 中にも示してある。

マイクロガスタービン発電設備（ここでは 1 台の定 格発電容量 $75 \mathrm{~kW}$ のもを想定した）の機器構成及び 重量構成を Table 2 に示す。MGT 発電設備は発電機 と一体をなすガスタービン本体, 再熱器, 電気機器等 より構成されパッケージ全体の重量はおよそ $1,500 \mathrm{~kg}$ である。各機器の重量は文献值 ${ }^{9)}$, カタログ值 ${ }^{10)}$ 及

Table 1 Electricity, hot/chilled water supply thermal efficiency

\begin{tabular}{l|l|c}
\hline & \multicolumn{1}{|c|}{ Apparatus } & Therm.effi. \\
\hline electricity & Grid electricity & $0.35^{3)}$ \\
& MGT & $0.28^{4)}$ \\
\hline \multirow{2}{*}{ hot/chilled } & Water heater & $0.85^{5)}$ \\
& Hot water absorption chiller & $0.65^{6)}$ \\
\multirow{3}{*}{ water } & Gas absorption chiller-heater & \\
& chilling & $0.95^{7)}$ \\
& heating & $0.85^{8)}$ \\
\hline
\end{tabular}


Table 2 Weight of $75 \mathrm{~kW}$ MGT

\begin{tabular}{c|l|c}
\hline & Instrument & $\begin{array}{c}\text { Instrument } \\
\text { weight } \\
\text { kg }\end{array}$ \\
\hline \multirow{7}{*}{ MGT } & Gas turbine & $75^{*}$ \\
& Compressor & $20^{*}$ \\
& Generetor & $65^{*}$ \\
& Recuperator & $260^{* *}$ \\
& Duct·piping & 75 \\
& Inverter & 25 \\
& Enclosure & $640^{9)}{ }^{10)}$ \\
& Transformer & $100^{9)}$ \\
& Battery & $122^{9)}$ \\
& Gas compressor & $159^{9)}$ \\
\hline
\end{tabular}

* allocated $160 \mathrm{~kg}$ of core turbine weight

* * caluculated from plate-fin with $1 \mathrm{~mm}$ thickness

びTable 2 の注釈に示すように，*印で示す機器の重 量をコアタービン (圧縮機, タービン, 発電機一体構 造）の総重量 $160 \mathrm{~kg}$ からそれぞれの図面寸法より按分 して求めた。また，**印で示す再生器は板厚 $1 \mathrm{~mm}$ のプレートフィン型熱交換器とし所要交換熱量より求 めた伝熱面積及びケーシングより重量を求めた。

3. MGT-CGS 運用時の省エネルギー及び $\mathrm{CO}_{2}$ 削減量 建物にMGT-CGS を導入する際の一次エネルギー の消費量は, 建物固有の熱電需要の時間的, 季節的変
動によって変化するため，ここではまず，MGT-CGS の従来型熱電供給システムに対する省エネルギー率を 明らかにし，省エネルギー率が最大となる場合につい て運用時 $\mathrm{CO}_{2}$ 発生量の削減量を比較する。

\section{1）省エネルギー率の算定}

MGT-CGS と従来型の系統電力＋ガス焚吸収冷温水 機システム各々の一次エネルギー投入量を比較するこ とにより，MGT-CGS の系統電力十ガス焚吸収冷温水 機システムに対する省エネルギー率を算定した。省エ ネルギー率の計算は, Table 3 に示す手続きによった。

まず前提として，両システムともに電力需要 $\mathrm{E}_{\mathrm{d}}$ お よび冷温熱需要 $\mathrm{H}_{\mathrm{cd}}, \mathrm{H}_{\mathrm{wd}}$ を満たさなければならない。 MGT-CGS では, 電力需要は MGT 発電 $\mathrm{E}_{\mathrm{mgt}}$ と一部分 補助の系統電力 $\mathrm{E}_{\mathrm{grd}}$ によりまかなう。そのために, (2), (3)式で示す熱量 $\mathrm{H}_{\mathrm{mgt}}, \mathrm{H}_{\mathrm{grd}}$ が投入され，(4)式で示 す排熱 $\mathrm{H}_{\mathrm{wst}}$ が発生する。ここで, MGT 発電では, 負 荷が低下した際に Fig. 2 に示すように発電効率が定格 発電時より低下する ${ }^{11)}$ ため(2)式での熱量の算定には, その影響を考虑した。なおここでは気温による効率の 変化については考慮していない。また, 系統電力の発 電効率は一般的に用いられている $35 \%{ }^{3)}$ とした。一 方，冷温熱需要をまかなうため(5), (6)式で示すように 発電排熱 $\mathrm{H}_{\mathrm{wst}}$ を用い不足分は補助熱量 $\mathrm{H}_{\mathrm{aux}}$ を投入す る。

系統電力十ガス焚吸収冷温水システムでは, 電力需

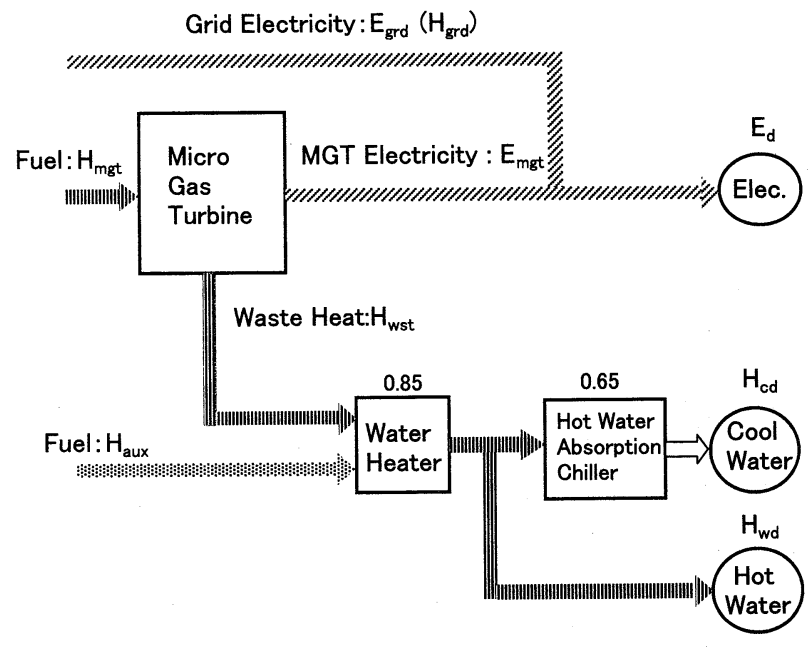

Micro Gas Turbine Cogeneration System
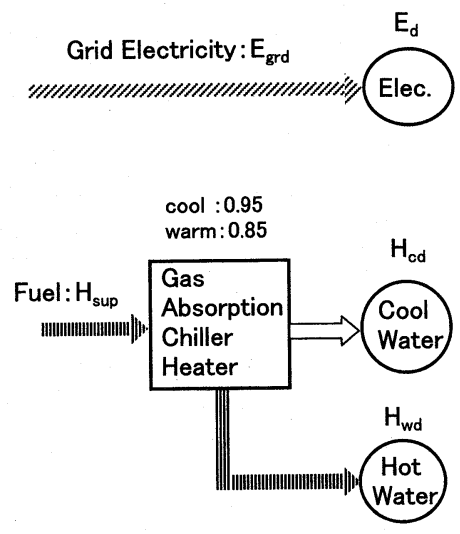

Grid Electricity

+ Gas Absorption Chiller-Heater

Fig. 1 Systems of MGT-CGS and ordinary electricity / heat supply 
Table 3 Formulas for calculation of system energy use and energy saving

\begin{tabular}{|c|c|c|c|c|c|}
\hline \multirow[b]{2}{*}{ Electricity } & \multirow[b]{2}{*}{$\begin{array}{l}\text { Electricity demand } \\
\text { Heat required for MGT } \\
\text { Heat required for grid } \\
\text { Waste heat from MGT }\end{array}$} & \multicolumn{2}{|l|}{ MGT-CGS } & \multicolumn{2}{|c|}{$\begin{array}{c}\text { Grid electricity+Gas absorption } \\
\text { heater and chiller }\end{array}$} \\
\hline & & $\begin{array}{l}\mathrm{E}_{\mathrm{d}}=\mathrm{E}_{\mathrm{mgt}}+\mathrm{E}_{\text {grd }} \\
\mathrm{H}_{\mathrm{mgt}}=0.86 \mathrm{E}_{\mathrm{mgt}} / 0.28^{*} \\
\mathrm{H}_{\mathrm{grd}}=0.86 \mathrm{E}_{\text {grd }} / 0.35 \\
\mathrm{H}_{\mathrm{wst}}=\mathrm{H}_{\mathrm{mgt}}(1-0.28)\end{array}$ & $\begin{array}{l}\text { (1) } \\
(2) \\
(3) \\
(4)\end{array}$ & $\begin{array}{l}\mathrm{E}_{\mathrm{d}}=\mathrm{E}_{\mathrm{grd}} \\
\mathrm{H}_{\mathrm{grd}}=0.86 \mathrm{E}_{\mathrm{grd}} / 0.35\end{array}$ & $\begin{array}{l}(8) \\
(9)\end{array}$ \\
\hline $\begin{array}{l}\text { Hot \& cool } \\
\text { heat }\end{array}$ & $\begin{array}{l}\text { Cool heat demand } \\
\text { Warm heat demand } \\
\text { Fuel (auxiliary, main) }\end{array}$ & $\begin{array}{l}\mathrm{H}_{\mathrm{cd}} \\
\mathrm{H}_{\mathrm{wd}} \\
\mathrm{H}_{\text {aux }}=\mathrm{H}_{\mathrm{cd}} /(0.85 \times 0.65)-\mathrm{H}_{\mathrm{wst}} \\
\mathrm{H}_{\text {aux }}=\mathrm{H}_{\mathrm{wd}} / 0.85-\mathrm{H}_{\mathrm{wst}}\end{array}$ & $\begin{array}{l}(5) \\
(6)\end{array}$ & $\begin{array}{l}\mathrm{H}_{\mathrm{cd}} \\
\mathrm{H}_{\mathrm{wd}} \\
\mathrm{H}_{\text {sup }}=\mathrm{H}_{\mathrm{cd}} / 0.95 \\
\mathrm{H}_{\text {sup }}=\mathrm{H}_{\mathrm{wd}} / 0.85\end{array}$ & $\begin{array}{l}(10) \\
(11)\end{array}$ \\
\hline \multicolumn{2}{|c|}{ Primary energy demand } & $\mathrm{H}_{\text {mgt }}+\mathrm{H}_{\mathrm{grd}}+\mathrm{H}_{\text {aux }}$ & (7) & $\mathrm{H}_{\text {grd }}+\mathrm{H}_{\text {sup }}$ & $(12)$ \\
\hline \multicolumn{2}{|c|}{ Energy saving } & \multicolumn{3}{|c|}{$1-\left(\mathrm{H}_{\text {mgt }}+\mathrm{H}_{\text {grd }}+\mathrm{H}_{\text {aux }}\right) /\left(\mathrm{H}_{\text {gd }}+\mathrm{H}_{\text {sup }}\right)$} & $(13)$ \\
\hline
\end{tabular}

* Thermal efficiency at rating capacity

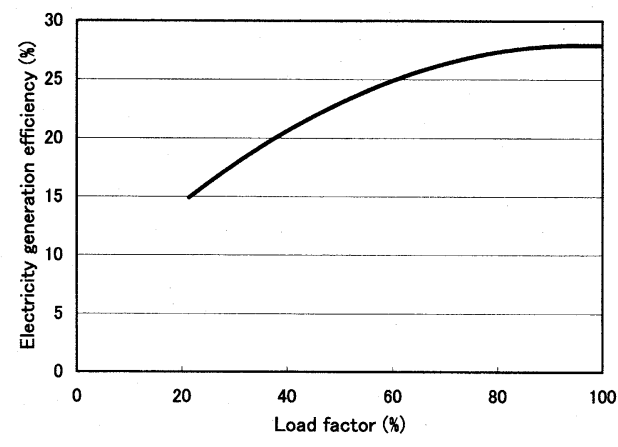

Fig. 2 Relation between electricity generation efficiency and load factor of MGT cogeneration

要は系統電力 $\mathrm{E}_{\mathrm{grd}}$ によりすべてまかなう。そのために, (9)式で示す熱量 $\mathrm{H}_{\mathrm{grd}}$ のみが投入され，発電所で発生 した排熱は利用されることなく廃棄される。一方，冷 温熱需要をまかなうため(10), (11)式で示すように熱量 $\mathrm{H}_{\text {sup }}$ を投入する。

その結果，一次エネルギー投入量が，MGT-CGS で は $\mathrm{H}_{\mathrm{mgt}}+\mathrm{H}_{\mathrm{grd}}+\mathrm{H}_{\mathrm{aux}}$, 系統電力十ガス焚吸収冷温水機シ ステムでは $\mathrm{H}_{\text {grd }}+\mathrm{H}_{\text {sup }}$ となる。

省エネルギー率は，(13)式で定義するように，従来 型の系統電力十ガス焚吸収冷温水機システムを基準と しこれからの一次エネルギー投入量削減率とした。 MGT 運転容量の最適化計算は，(7)式をべクトル表示 した(14)式で示す MGT の発電用一次エネルギー, 補助 系統電力発電用一次エネルギー, 補助熱エネルギーの 一日間の和で表される関数を，(15), (16)式のもとで最小 化するような MGT 運転容量 $\mathrm{E}_{\mathrm{mgt}}(i, j)$ を求める方 法によった。ここで $i$ は時刻 $(1 \sim 24$ 時), $j$ は何台目
（0～3台）の MGT が運転されているかを表す添字, クは発電効率であり MGTでは負荷率により変化す る。

$$
\begin{aligned}
\sum_{i}\left(\sum_{j}\right. & 0.86 \mathrm{E}_{\mathrm{mgt}}(i, j) / \eta \mathrm{mgt} \\
& \left.+0.86 \mathrm{E}_{\mathrm{grd}}(i) / \eta \operatorname{grd}\right) \\
& \rightarrow \text { minimize }
\end{aligned}
$$

$\mathrm{H}_{\text {wst }}(i)+\mathrm{H}_{\text {aux }}(i) \geqq \mathrm{H}_{\mathrm{d}}(i)$

$\sum_{j} \mathrm{E}_{\mathrm{mgt}}(i, j)+\mathrm{E}_{\mathrm{grd}}(i)=\mathrm{E}_{\mathrm{d}}(i)$

熱電比の高い時間带では, 次式

$$
\mathrm{H}_{\text {dis }}(i)=\mathrm{H}_{\mathrm{wst}}(i)-\mathrm{H}_{\mathrm{d}}(i)
$$

で表される熱量 $\mathrm{H}_{\mathrm{dis}}(i)$ が廃棄熱となる。

\section{2）対象建屋及び熱電需要}

ここでは一例として延床面積 $12,000 \mathrm{~m}^{2}$ の集合住宅, 及び延床面積 3,000 $\mathrm{m}^{2}$ のスーパーマーケットに導入す る場合について考察する。これらの建物を選定した理 由は，いずれも比較的小規模であり，これらは都市の 中にごく普通に存在してしかも両者が近接している場 合が多いため, 単独あるいは共有させる形態でマイク ロガスタービンコジェネレーションを導入するのに適 していると考えられたことによる。

これらの建物の電力及び冷温熱需要の各季節での日 負荷率 (=一日の平均需要量/一日の最大需要量) を Table 4 に示す。熱需要は, 集合住宅については臨海 副都心での 2005 年見通し值 ${ }^{12)}$, スーパーマーケット については光が丘清掃工場での熱供給害績のヒアリン 
グ值より算出した。電力需要は，集合住宅については 文献 13）より，スーパーマーケットについては文献 14） より求めた。電力は，照明その他に使われる需要を示 し，冷暖房用に使用されるものは含まない。従って， ここでは季節による電力需要には差がないものとし た。

\section{3）建屋個別に導入した場合}

集合住宅，スーパーマーケットそれぞれ個別に MGT-CGS を導入した際の，省エネルギー率及び $\mathrm{CO}_{2}$ 排出について考察する。

ここで，一例として示した $3,000 \mathrm{~m}^{2}$ 規模のスーパー マーケット熱源機器は現状ではヒートポンプが使用さ れているケースが多いと思われるが, 電力ピークカッ 卜，運用時の経済性の面から今後導入が増すと考え， システムではガス吸収式冷温水機を選定した。はじめ に，それぞれの建屋において省エネルギー率が最大と なる MGT 運転容量を求めた。Fig. 3 に計算結果を示 す。省エネルギー率は MGT 運転容量によって変化し, 集合住宅では, 夏季には運転容量 $60 \mathrm{kWh} / \mathrm{h}$, 冬季に は $145 \mathrm{kWh} / \mathrm{h}$, 中間期には $5 \mathrm{kWh} / \mathrm{h}$ で最大の省エネル ギー率が達成され，スーパーマーケットでは夏季には $145 \mathrm{kWh} / \mathrm{h}$ ，冬季には $5 \mathrm{kWh} / \mathrm{h}$ ，中間期には $70 \mathrm{kWh} / \mathrm{h}$ で最大の省エネルギー率が達成されることがわかる。 このとき電力が MGT 発電電力と系統電力のどちらで どれだけ供給されているかをFig. 4 に示した。MGT 発電は前述のように定格容量 $75 \mathrm{~kW}$ のもとしこれを 複数台設置するものとした。集合住宅では，夏季には 電力を MGT1 台と系統電力により供給し, 冬季には 全ての電力を MGT1 ～2台により，中間期はほとん どを系統より供給する。これに対してスーパーマーケ

Table 4 Seasonal daily load ratio of buildings

\begin{tabular}{l|l|r|r|r}
\hline \multirow{2}{*}{ Season } & \multirow{2}{*}{\begin{tabular}{l} 
Energy \\
\cline { 3 - 5 }
\end{tabular}} & $\begin{array}{l}\text { Apartment } \\
\text { house } \\
\left(12,000 \mathrm{~m}^{2}\right)\end{array}$ & $\begin{array}{l}\text { Super } \\
\text { market } \\
\left(3,000 \mathrm{~m}^{2}\right)\end{array}$ & $\begin{array}{l}\text { Commonly } \\
\text { supply } \\
\left(15,000 \mathrm{~m}^{2}\right)\end{array}$ \\
\hline Summer & Electricity & 64.1 & 44.8 & 59.2 \\
& Cool heat & 44.5 & 50.1 & 49.8 \\
& Warm heat & 63.0 & 41.7 & 60.4 \\
\hline Winter & Electricity & 52.7 & 45.8 & 63.5 \\
& Cool heat & 58.2 & 46.8 & 49.4 \\
& Warm heat & 55.5 & 54.0 & 56.3 \\
\hline Medium & Electricity & 56.3 & 44.8 & 58.7 \\
season & Cool heat & 45.3 & 47.3 & 47.7 \\
& Warm heat & 55.8 & 52.4 & 63.6 \\
\hline
\end{tabular}
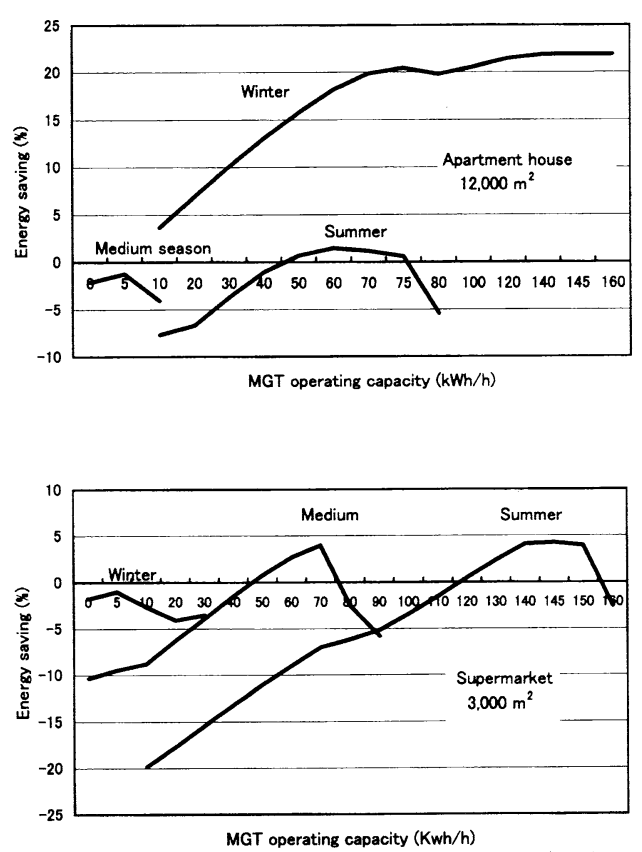

Fig. 3 Optimum operation capacity of MGT installed for apartment-house and supermarket respectively

ットでは，夏季には大部分を MGT2 台で供給し，冬 季にはほとんどを系統より，中間期には MGT1 台と 系統より供給する運転がなされる。

このときのそれぞれの建屋での熱需要をまかなうた めの熱源機器への熱供給の状況を Fig. 5 に示した。各 建屋の所要熱量に対して MGTの排熱でまかなった熱 量, 余剰となり廃棄した熱量, 及び排熱が不足して補 助然料によってまかなった熱量のそれぞれについて示 した。集合住宅 $\left(12,000 \mathrm{~m}^{2}\right)$ では, 夏季は所要熱量の すべてを MGT 排熱でまかなうことができる。一方で, これと同程度の廃熱が使われずに廃棄されることがわ かる。冬季は電力のすべてを MGTでまかなう運転を 行うが, 昼間は電力需要が少ないため所要熱量に対し て排熱量が不足し補助熱量が必要となる。スーパーマ ーケット $\left(3,000 \mathrm{~m}^{2}\right)$ では, 夏季には昼間は熱需要を 排熱によってまかなうことができ廃棄される熱もほと んどないが，夜間には電力需要がわずかになるため補 助熱量が必要となる。冬季は熱需要が少ないため, MGTによる電力供給を抑えており補助熱量が必要で ある。中間期も夜間における補助熱量を必要としてい る。

Table 5 にそれぞれの建屋について季節別の MGT 運転容量, MGT-CGS 及び従来型熱電供給システムの 


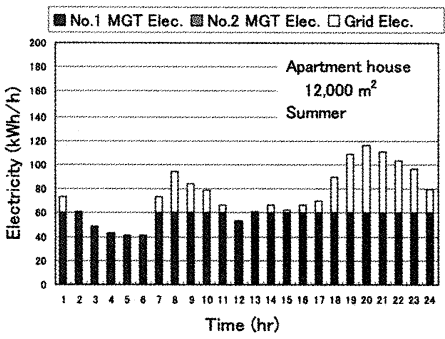

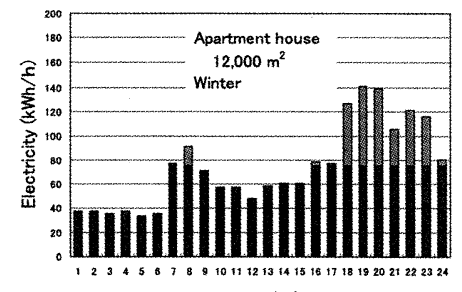

Time (hr)

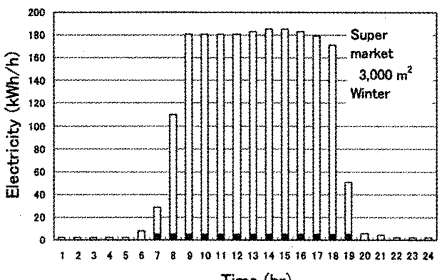

Time (hr)
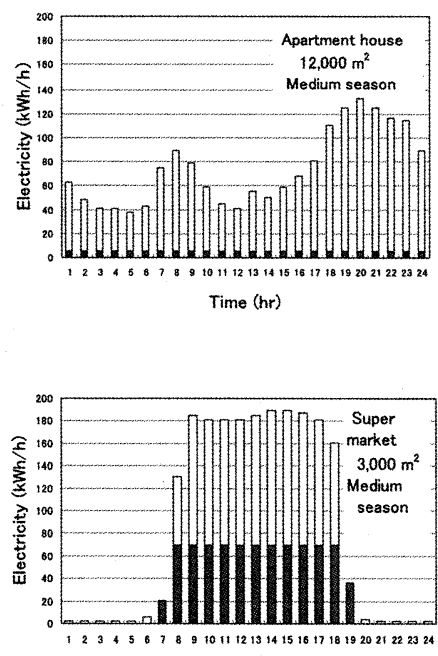

Time (hr)

Fig. 4 Share of MGT and grid electricity in supplying electricity to apartment-house and supermarket respectively
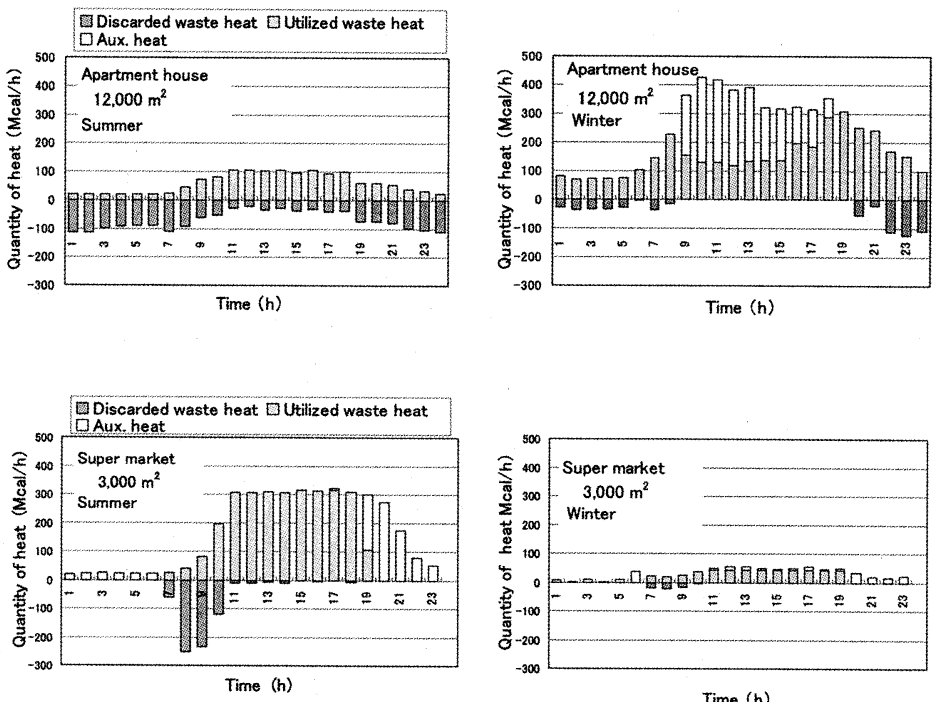

Fig. 5 Utilization of waste heat and auxiliary heat (supplied to apartment-house and supermarket respectively)

エネルギー (一次エネルギー換算) 使用量，ならびに 最大省エネルギー率及び $\mathrm{CO}_{2}$ 排出削減率をまとめて 示す。MGT導入による集合住宅での省エネルギー率 は 8.3\%，スーパーマーケットでの省エネルギー率は $2.9 \%$ であり，個別に設置して合計した省エネルギー 率は $5.7 \%$ となった。また, $\mathrm{CO}_{2}$ 排出削減率は集合住 宅では $2.7 \%$, スーパーマーケットではー 3.7\% となり, 合計した $\mathrm{CO}_{2}$ 排出削減率はー $0.7 \%$ と従来型 CGSに 比較して $\mathrm{CO}_{2}$ 排出量は若干増加した。
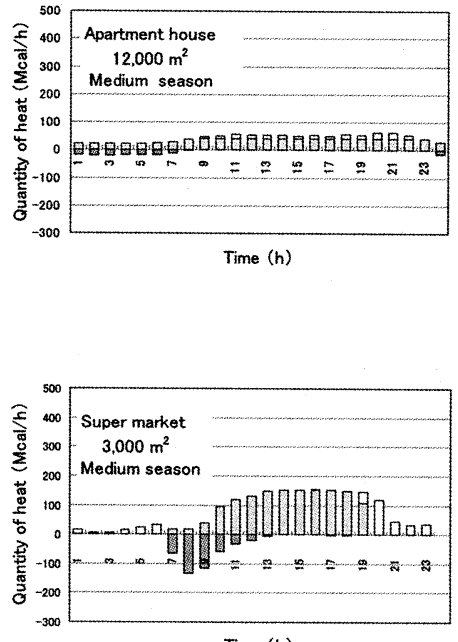

\section{4 ）建屋共有で導入した場合}

次に，集合住宅，スーパーマーケットの間でMGTCGS を共有で導入した際の，省エネルギー率及び $\mathrm{CO}_{2}$ 排出について考察する。個別導入の場合と同様, 共有の場合にも省エネルギー率が最大となるように MGT 運転容量が決まる。Fig. 6 に MGT 導入容量と省 エネルギー率の関係を示す。夏季では $210 \mathrm{kWh} / \mathrm{h}$ の運 転容量で最大 $7.2 \%$, 冬季では $215 \mathrm{kWh} / \mathrm{h}$ で最大 25.1 $\%$ ，中間期では $75 \mathrm{kWh} / \mathrm{h}$ で最大 $6.2 \%$ の省エネルギー 
Table 5 Energy saving and $\mathrm{CO}_{2}$ reduction in operating stage of MGT-CGS and grid electricity + gas chiller / heater installed in apartment house and supermarket respectively

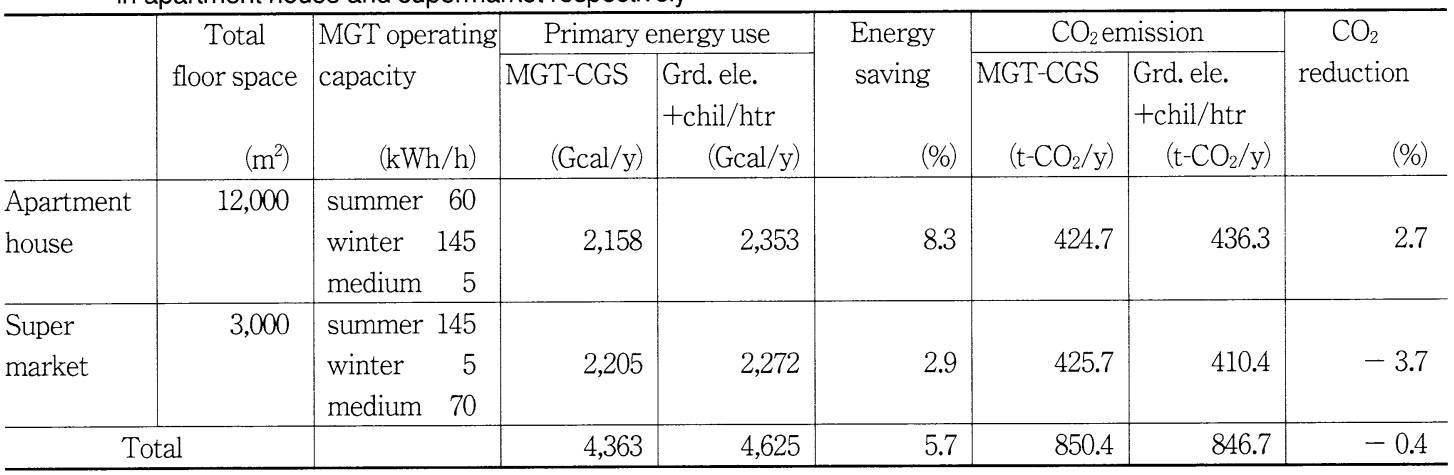

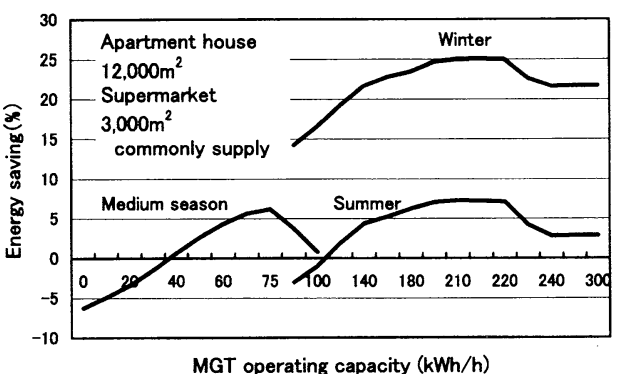

Fig. 6 Optimum operation capacity of MGT installed for apartment-house and supermarket in common
となった。このときのそれぞれの季節における電力の 供給形態を Fig. 7 に示す。夏季, 冬季はほとんど全日 MGT による供給がおこなわれる。昼間 8〜18 時の間 には 3 台の MGT が運転され，一部分系統電力との併 用がなされる。中間期は MGT の運転は 1 台に抑えら れ，残りは系統より供給される。

このときの共有建屋での熱供給の状況を Fig. 8 に示 した。Fig. 4 と比較すると, 建屋間で MGT-CGS を共 有することによって，個別に設置したときの冬季の集 合住宅に見られたような昼間の補助熱及び夏季のスー パーマーケットへの夜間の補助熱が不要となり，年間 の補助熱の削減が可能になることがわかる。その結果,
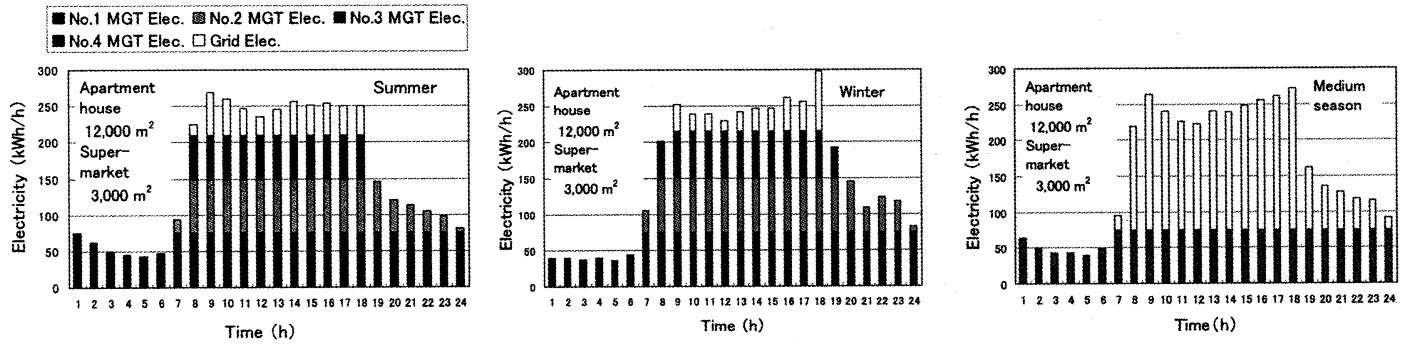

Fig. 7 share of MGT and grid electricity in supplying electricity to apartment-house and supermarket in common
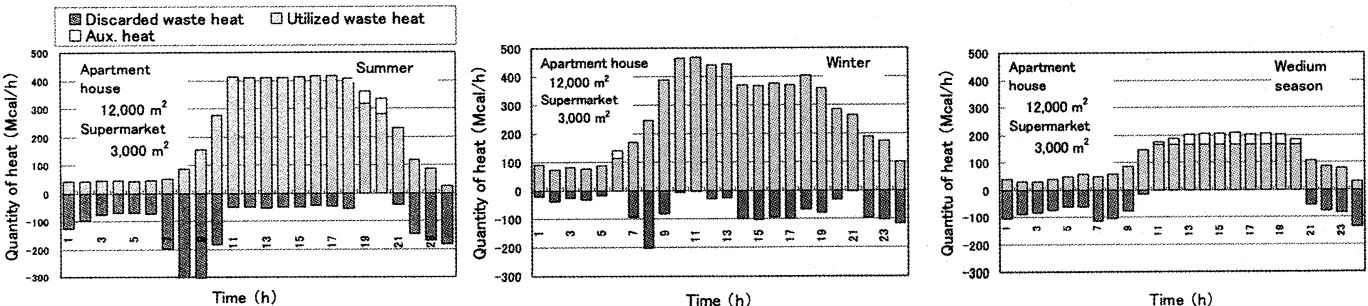

Fig. 8 Utilization of waste heat and supply of auxiliary heat (supplied to apartment-house and supermarket in common) 
Table $6 \mathrm{CO}_{2}$ emission in operation stage of MGT-CGS and grid electricity +gas chiller-heater installed in apartment house and supermarket in common

\begin{tabular}{|c|c|c|c|c|c|c|}
\hline & \multicolumn{4}{|c|}{ MGT-CGS } & \multicolumn{2}{|c|}{$\begin{array}{c}\text { Grid electricity } \\
+ \text { Gas chiller/heater }\end{array}$} \\
\hline & & $\begin{array}{l}\text { Town gas } \\
\text { Mcal/d }\end{array}$ & $\begin{array}{l}\text { Grid electr. } \\
\mathrm{kWh} / \mathrm{d}\end{array}$ & $\begin{array}{c}\text { Auxialy fuel } \\
\text { Mcal/d }\end{array}$ & $\begin{array}{c}\text { Town gas } \\
\text { Mcal/d }\end{array}$ & $\begin{array}{c}\text { Grid electr. } \\
\mathrm{kWh} / \mathrm{d}\end{array}$ \\
\hline Energy & August & $10,626.1$ & 432.7 & 96.2 & $3,309.4$ & $3,824.6$ \\
\hline \multirow[t]{3}{*}{ input } & January & $10,860.6$ & 359.4 & 26.9 & $6,313.6$ & $3,824.6$ \\
\hline & May & $5,076.7$ & $2,184.6$ & 333.6 & $2,091.7$ & $3,824.6$ \\
\hline & Annual prim. & \multicolumn{3}{|c|}{$4,060.1 \mathrm{Gcal} / \mathrm{y}$} & \multicolumn{2}{|c|}{ 4,625.7 Gcal/y } \\
\hline \multicolumn{3}{|c|}{ Annual energy saving } & \multicolumn{2}{|l|}{$12.2 \%$} & & \\
\hline \multicolumn{7}{|c|}{ Annual $\mathrm{CO}_{2}$ emission(ton/y) } \\
\hline \multicolumn{2}{|c|}{ Each energy } & 603.7 & 196.8 & 15.1 & 263.4 & 583.2 \\
\hline \multicolumn{2}{|l|}{ Total } & \multicolumn{3}{|c|}{$815.6 \mathrm{t}-\mathrm{CO}_{2}$} & \multicolumn{2}{|c|}{846.6} \\
\hline Annual C & iction $(\% / y)$ & \multicolumn{3}{|c|}{$3.7 \%$} & \\
\hline
\end{tabular}

Table 6 に示すように MGT-CGS では従来型熱電供給 システムに比べ年間 $12.2 \%$ の省エネルギー率となっ た。このとき $\mathrm{CO}_{2}$ 排出量削隇率は $3.7 \%$ となった。省 エネルギー率が大きい割には $\mathrm{CO}_{2}$ 排出量削減率が大 きくないのは, 発電時の $\mathrm{CO}_{2}$ 排出原単位が $\mathrm{MGT}$ 発電 の方が系統電力発電よりも大きいためである。最近で は，分散型発電はピーク電力削減に寄与するのである から, 系統電力の $\mathrm{CO}_{2}$ 排出原単位はピーク発電時の 火力発電割合の高い時の值をとって比較するという考 え方があり，その場合は $\mathrm{CO}_{2}$ 排出量削減率は上記の 值より大きくなるが，ここでは平均の原単位を用いた。 ここで, Fig.5, Fig.8において個別, 共有ともに省工 ネルギー率が最大であるにもかかわらず熱廃棄量が大 きいのは，この場合所要熱量の大部分を MGT 排熱で まかない補助熱をほとんど必要としないが，時間帯に よって熱電比に相違があるため，ある時間帯では排熱 が余り廃棄熱量が発生するためである。

以上のように, 省エネルギー性, $\mathrm{CO}_{2}$ 削減のいずれ に㧍いても MGT-CGS を建屋間で共有する方が個別に 設置するよりも有利であることが示された。

\section{MGT-CGS 導入時の環境評価}

MGT-CGS の製造に始まり運転に至るまでのライフ サイクルでの $\mathrm{CO}_{2}$ 排出量を従来型熱電供給システム と比較する。

\section{1 設備製造時}

共有設置の場合，Fig. 7 に示したように年間を通じ ての MGT の最大運転台数は $75 \mathrm{~kW}$ のものが 3 台であ る。廃熱ボイラについては, 冬季の温熱最大需要量が
Table 4 の日負荷率 $56.3 \%$ と，一日の温熱需要パター ンより求まる平均温熱需要量 $218.1 \mathrm{Mcal} / \mathrm{h}$ より, 387.4 $\mathrm{Mcal} / \mathrm{h}$ と求まるので, 容量は余裕 $20 \%$ をみて 470 $\mathrm{Mcal} / \mathrm{h}$ ，台数は低負荷時の効率低下を考慮して 2 台 とし 1 台の容量を $235 \mathrm{Mcal} / \mathrm{h}$ とした。ここで，余裕 $20 \%$ は，例えば文献 15）で仮定されている需要変動 の不確実性の例を参考にした。同様に，冷熱供給に対 しては冷熱の最大需要が $217.3 \mathrm{Mcal} / \mathrm{h}$ と求まるので, 温水吸収冷凍機は余裕 $20 \%$ をみて容量 $260 \mathrm{Mcal} / \mathrm{h}$ (90USRT), 台数は吸収冷凍機では低負荷時 COP 低 下がほとんどないため，1台でまかなうものとした。 また, 従来型 CGS のガス焚き吸収冷温水機は, 温水 供給容量 $465 \mathrm{Mcal} / \mathrm{h}$ （冷熱供給能力は $180 \mathrm{USRT}$ ）の もの 1 台を設置する。これらの MGT-CGS 及び従来 型 CGS 設備の素材別重量を求め，素材の製造に伴っ て排出される $\mathrm{CO}_{2}$ 量及び加工・組立て工程で排出さ れる $\mathrm{CO}_{2}$ 量を計算した。上記の容量の機器一台あた りの $\mathrm{CO}_{2}$ 排出量計算結果を Table 7 に示す。部品の 材質についてはガスタービンで使われる材質を参考 ${ }^{16)}$ にして推定した。計算に用いた素材製造時の $\mathrm{CO}_{2}$ 発 生原単位は表下部の註に示す資料及び方法によっ た ${ }^{17)}{ }^{18)}$ 。MGT 発電設備素材からの $\mathrm{CO}_{2}$ 発生量はお よそ 3.67 ton, 廃熱ボイラ素材からの $\mathrm{CO}_{2}$ 発生量はお よそ2.19ton, 温水吸収冷凍機素材からの $\mathrm{CO}_{2}$ 発生量 は扔よそ8.97ton であった。加工·組立てには，鋳造， 鍛造, 溶接, ろう付け等があり, そのエネルギー原単 位は一部文献值 ${ }^{17)}$, 及び作業現場からの聴取デー夕 によった。また，エネルギー種別ごとの $\mathrm{CO}_{2}$ 発生原 単位は Table 8 に示す值 ${ }^{18)}$ を用いた。加工·組立て時 のエネルギー消費に伴う $\mathrm{CO}_{2}$ の発生量は, MGT 発電 


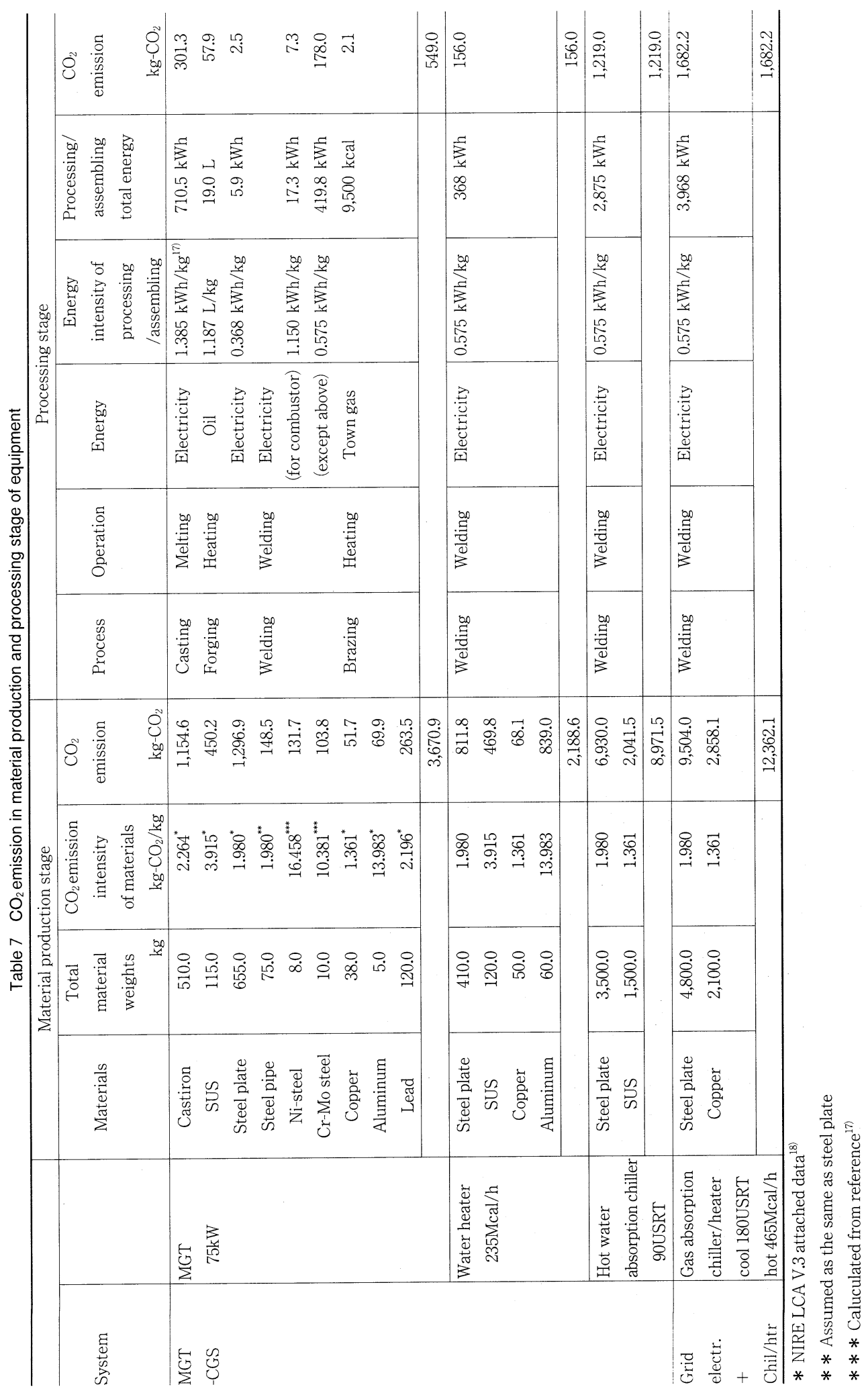


設備 0.55 ton $-\mathrm{CO}_{2}$, 排熱ボイラ 0.16 ton $-\mathrm{CO}_{2}$, 温水吸収 冷凍機 1.22 ton- $\mathrm{CO}_{2}$ であった。従来型熱電供給システ ムでは, Table 7 に示すように, 素材製造に伴って発 生する $\mathrm{CO}_{2}$ 発生量は 12.36 ton- $\mathrm{CO}_{2}$, 加工・組立て時 1.68 ton- $\mathrm{CO}_{2}$ ，合計 14.04 ton- $\mathrm{CO}_{2}$ であった。

個別設置の場合についても, それぞれの建屋に設置 する機器容量を同様の方法で決定することができ，素 材製造, 加工·組立ての際の $\mathrm{CO}_{2}$ 発生量がもとめられる。

Table 9 に集合住宅とスーパーマーケットの例にお いて，熱電供給システムを個別に設置する場合と共有 で設置する場合のシステム製造時の $\mathrm{CO}_{2}$ 排出量を示 す。その結果, 製造時の $\mathrm{CO}_{2}$ 排出量は共有時は MGTCGS では 27.54ton- $\mathrm{CO}_{2}$, 従来型では 14.04ton- $\mathrm{CO}_{2}$ で あったのに対し，個別設置時は共有の場合に比較して MGT-CGS, 従来型ともに機器の台数が増加するため, MGT-CGS では 39.76ton- $\mathrm{CO}_{2}$, 従来型では 21.56ton$\mathrm{CO}_{2}$ であり共有設置の場合よりも $\mathrm{CO}_{2}$ が増加する。

一方, 運転時の $\mathrm{CO}_{2}$ 発生量は共有時は Table 6 で示

Table $8 \quad \mathrm{CO}_{2}$ emission intensities of energy

\begin{tabular}{l|c}
\hline Energy & $\mathrm{CO}_{2}$ emission intencity \\
\hline Electricity & $0.424 \mathrm{~kg}-\mathrm{CO}_{2} / \mathrm{kWh}{ }^{18)}$ \\
Town gas & $0.212 \mathrm{~kg}-\mathrm{CO}_{2} / \mathrm{Mcal}^{18)}$ \\
\hline
\end{tabular}

したように MGT-CGS では 815.6t-CO $\mathrm{CO}_{2} / \mathrm{y}$ ，従来型では 846.6t- $\mathrm{CO}_{2} / \mathrm{y}$ であった。また，個別設置時の合計は Table 5 に示したように MGT-CGS では 850.4t- $\mathrm{CO}_{2} / \mathrm{y}$, 従来型では $846.7 \mathrm{t}-\mathrm{CO}_{2} / \mathrm{y}$ であった。

以上のように，共有設置時には MGT-CGS では設 備製造時の $\mathrm{CO}_{2}$ 発生量は従来型システムに比べてお

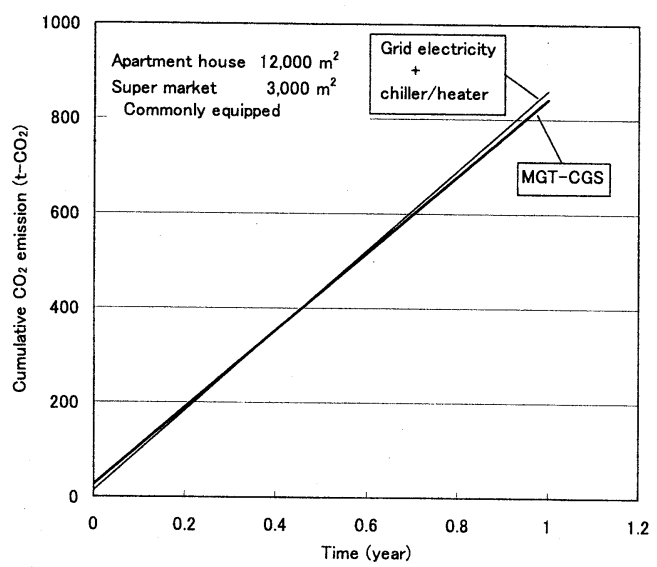

Fig 9 Cumulative $\mathrm{CO}_{2}$ emission from MGT-CGS and grid electricity + chiller/heater system installed for apartment-house and supermarket

Table $9 \mathrm{CO}_{2}$ emission in production stages of systems installed for $12,000 \mathrm{~m}^{2}$ apartment house and $3,000 \mathrm{~m}^{2}$ supermarket

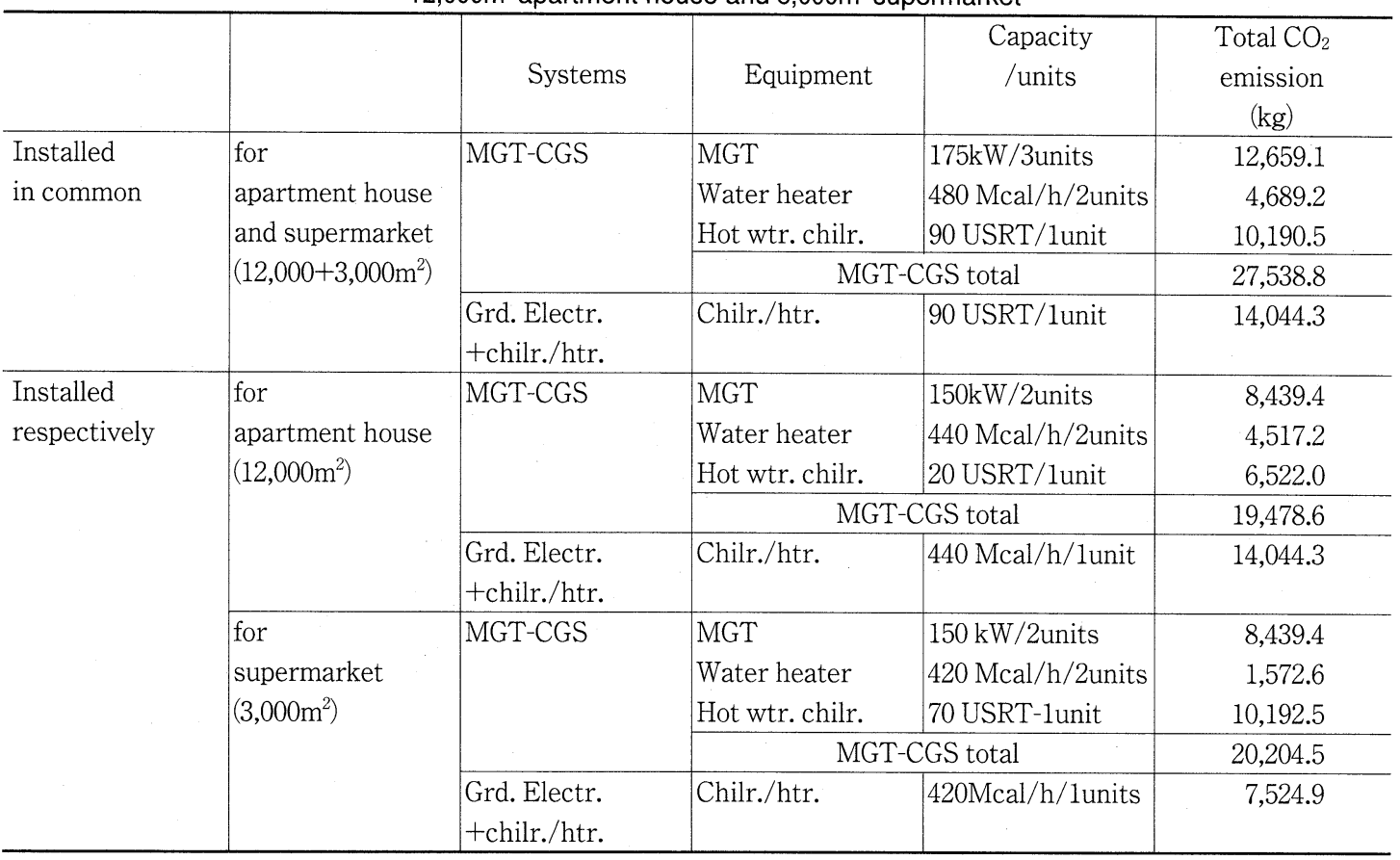


よそ $13.50 \mathrm{t}-\mathrm{CO}_{2}$ 大きいが，運用時には省エネルギー率 が大きいため，年間 $\mathrm{CO}_{2}$ 発生量が MGT-CGS の方が およそ31.0ton- $\mathrm{CO}_{2}$ 小さい。また，個別設置時には MGT-CGS では設備設置時の $\mathrm{CO}_{2}$ 発生量は従来型シス テムに比べておよそ 18.2 ton $-\mathrm{CO}_{2}$ 大きく，また運用時 も拈よそ3.7ton- $\mathrm{CO}_{2}$ 大きい。両システムの累積 $\mathrm{CO}_{2}$ 発生量を求めた結果を Fig. 9 に示す。両直線が交差す るときの年数を $\mathrm{CO}_{2}$ ペイバックタイムと定義 ${ }^{19)}$ す ると，従来型熱電供給システムを基準にした MGT$\mathrm{CGS}$ の $\mathrm{CO}_{2}$ ペイバックタイムは集合住宅とスーパー マーケット共有で設置した際は 0.43 年であった。一 方，それぞれ個別に設置する際は，上記のように MGT-CGS は設備製造時，運用時の $\mathrm{CO}_{2}$ 排出量がいず れも従来型熱電供給システムの排出量を上まわるた め， $\mathrm{CO}_{2}$ をペイバックできないことが示された。以 上の例からわかるように, MGT-CGS は従来型の熱電 供給システムに比較して，建物個別に設置するよりも 共有に設置する方が省エネルギー, $\mathrm{CO}_{2}$ 排出量削減に 有利である。

\section{5. 結 言}

マイクロガスタービンを用いるコジェネレーション システム（MGT-CGS）及び従来型電熱供給システム (系統電力十ガス焚吸収冷温水機) について，製造か ら運用に至るライフサイクルでの環境影響及び運転時 のエネルギー消費量を，一例として集合住宅（延床面 積 $12,000 \mathrm{~m}^{2}$ ） とスーパーマーケット（延床面積 3,000 $\left.\mathrm{m}^{2}\right)$ にシステムを共有で導入する場合と個別に導入 する場合について， $\mathrm{CO}_{2}$ 排出量により評価した。 MGT-CGS と従来型システムの運転時の一次エネルギ 一消費量を比較すると，共有で設置する場合 MGTCGS は従来型システムに比べ抢よそ $12.2 \%$ の省エネ ルギーとなり，個別設置での $5.7 \%$ に比較して高くな ることが示された。共有時のシステム運転時の年間 $\mathrm{CO}_{2}$ 排出量は MGT-CGS では従来型システムに比べお よそ $3.7 \%$ の削減となった。システムの設備製造から 運用時にわたるライフサイクル $\mathrm{CO}_{2}$ 発生量より求め た MGT-CGS の従来型システムに対する $\mathrm{CO}_{2}$ ペイバ ックタイムは 0.43 年であった。一方，個別に設置す る場合は設備製造時の発生 $\mathrm{CO}_{2}$ をペイバックできな いことが示された。

\section{文献}

1) 上甲勝弘，伊藤弘一，横山良平，蒲生恵司，多目 的最適化手法に基づくマイクロガスタービン・コ ジェネレーションシステムの導入可能性検討，第
17 回エネルギーシステム・経済・環境コンファレ ンス講演論文集，543（2001）

2 ) 安芸裕久, 大山 力, 辻毅一郎, 総合的なエネル ギー供給に扔けるマイクロガスタービン導入とエ ネルギー料金変化に関する分析，第 17 回エネル ギーシステム・経済·環境コンファレンス講演論文 集, 537 (2001)

3 ) 永田和彦，山地憲治，季節別料金制度下での連携 コジェネレーションシステムの解析・評価, 第 15 回エネルギーシステム・経済・環境コンファ レンス講演論文集，251（1999）

4 ）東京貿易 (株)，日本ガスタービン学会誌，27, 94 (1999)

5 ) Unifin International, Inc. Web site http://www.unifin.com/micogen.htm

6) 都市ガスによるコジェネレーションシステム計 画・設計と評価，空気調和衛生工学会

7) メーカーカタログ值

8) 同上

9 ）東京貿易 (侏，日本ガスタービン学会誌，27，94 (1999)

10）東京貿易 (株)，カタログ $75 \mathrm{~kW}$ TurboGenerator ${ }^{\mathrm{TM}}$ ガスタービン発電装置

11）三浦千太郎，マイクロガスタービンの技術開発の 現状，省エネルギー，52，22(2000)

12）東京都清掃局，清掃工場余熱利用推進化調査報告 書（その 2) (1992)

13）住環境計画研究所, 家庭の省エネルギー診断のた めのモニターアンケート調查報告書（1999）

14）東京都環境保全局，都におけるエネルギー需給構 造調査報告書 (1999)

15）蒲生恵司，伊東弘一，横山良平，エネルギー需要 の不確実性を考慮した家庭用コジェネレーション の導入可能性分析，第 18 回エネルギーシステ ム・経済・環境コンファレンス講演論文集, 287 (2002)

16）日本機械学会，機械工学便覽応用編，B4-50 (1998)

17）(社) 資源協会，先導的資源技術の総合評価に関す る基礎調查報告書（1991）

18）産業技術総合研究所, NIRE LCA V 3.0 付属デー 夕 $(2001)$

19）田原聖隆，小島紀德，稲葉 敦，LCA 手法によ る発電プラントの評価一 $\mathrm{CO}_{2}$ ペイバックタイム の算出一, 化学工学論文集, 23,88 (1997) 


\title{
Evaluation of Energy Saving and Environmental Factor in Micro Gas Turbine Co-generation System Application
}

\author{
Norio ARASHI, Yutaka GENCHI, Hiroshi YAGITA, and Atsushi INABA \\ (National Institute of Advanced Industrial Science and Technology)
}

SYNOPSIS : - It can be supposed that introduction of MGT-CGS to small-medium size buildings will increase in future from the view point of energy saving and global environment because of its suitable capacity to such buildings and high efficiency. In this paper environmental burden of MGT-CGS was evaluated in terms of $\mathrm{CO}_{2}$ emission in both production and operation stages of the system. Investigation was proceeded for the case in which MGT-CGS was applied to an apartment house (floor space 12,000 $\mathrm{m}^{2}$ ) and a super market (floor space $3,000 \mathrm{~m}^{2}$ ) as an example. The result was compared with that of grid electricity and heat supply system with absorption chiller-heaters. The possibility of $\mathrm{CO}_{2}$ emission reduction was clearly illustrated when the MGT-CGS was installed for an apartment house and a supermarket in common, on the contrary $\mathrm{CO}_{2}$ emission was increased in the case of application to each building respectively.

MGT-CGS was more energy saving and less $\mathrm{CO}_{2}$ emission system in operation stage, although in production stage MGT-CGS emits more $\mathrm{CO}_{2}$ than the ordinary system. This $\mathrm{CO}_{2}$ difference in production stage can be compensated in short time by the large annual $\mathrm{CO}_{2}$ emission reduction in operation. The time was 0.43 years in terms of $\mathrm{CO}_{2}$ pay back.

\section{Key Words}

Micro gas turbine, Co-generation, Energy saving, $\mathrm{CO}_{2}$ emission, LCA 